Scholarship Repository

University of Minnesota Law School

Articles

Faculty Scholarship

2011

\title{
Competitiveness in State Supreme Court Elections, 1945-2009
}

Herbert M. Kritzer

University of Minnesota Law School, kritzer@umn.edu

Follow this and additional works at: https://scholarship.law.umn.edu/faculty_articles

Part of the Law Commons

\section{Recommended Citation}

Herbert M. Kritzer, Competitiveness in State Supreme Court Elections, 1945-2009, 8 J. EMPIRICAL LEGAL STUD. 237 (2011), available at https://scholarship.law.umn.edu/faculty_articles/5.

This Article is brought to you for free and open access by the University of Minnesota Law School. It has been accepted for inclusion in the Faculty Scholarship collection by an authorized administrator of the Scholarship Repository. For more information, please contact lenzx009@umn.edu. 


\title{
Competitiveness in State Supreme Court Elections, 1946- 2009
}

\author{
Herbert M. K ritzer*
}

There has been much debate over changes in state supreme court el ections. However, most of the research that debate refers to considers a relatively short time span. This article reports an analysis of contestation and competitiveness in state supreme elections for the entire post-W orld W ar II period. The paper considers both primary and general elections (other than retention elections). The central finding of the paper is that outside the South there has been surprisingly little change, either in whether incumbents are challenged for reelection or in the competitiveness of the elections that are contested (looking separately at open seat elections and elections involving incumbents). The analysis suggests that the apparent increase in competiveness (taken to include the question of whether or not an incumbent is challenged), at least through 2009, reflects factors other than changes in the nature of campaigns and expenditures on state supreme court elections; specifically, those changes largely result from the end of the one-party South

\section{INTRODUCTION}

In this article, I examine one dimension of change in state supreme court el ections:

competitiveness. Specifically, has the likelihood increased that elections for seats on the various

\footnotetext{
* Address correspondence to Herbert M. K ritzer, University of M innesota L aw School, $22919^{\text {th }}$ A venue South, M inneapolis, M N 55455; email: kritzer@umn.edu. kritzer is the Marvin J. Sonosky Chair of Law and Public Policy and Affiliated Professor of Political Science at the U niversity of M innesota.

A ssembling the data for the analysis presented in this paper proved to be a significant undertaking. While for many states the information is readily available online or in published form (e.g., in state "blue books," "legislative manuals," and the like), for others the information is to be found only available in archives or in local newspapers which could be obtained only on microfilm via interlibrary loan. I received tremendous assistance in this endeavor from reference librarians and interlibrary loan staff at the U niversity of W isconsin Law Library, the William $M$ itchell College of Law Library, and the U niversity of M innesota L aw Library. A number of individuals in state election offices were extremely helpful and responsive, as were a number of scholars who provided me with data from their states and/or answered questions about possible sources for their states. I would particularly like to thank J ess Clayton who worked as a project assistant for me at the U niversity of W isconsin. M elinda Gann Hall generously provided me with tabulations she had done based on data compiled by the B rennan Center; A dam Skaggs at the B rennan Center provided with a prelease copy of the Center's 2010 report and spreadsheets with data on advertising in 2006 and 2008. Reviewers for the J ournal of E mpirical Legal Studies provided several valuable suggestions. Finally, I acknowledge support I received from the U niversity of W isconsin Graduate School and the University of W isconsin Political Science Department.
} 
courts will be contested and, for those that are contested, are the elections more likely to be competitive? The issue is relevant for the recurring debate over judicial selection in the states, a debate that is likely to increase in intensity in the wake of the Supreme Court's decision in Citizens U nited v. F ederal Election Commission, 558 U.S. (2010), a decision which has the potential to produce a flood of corporate expenditures in judicial, as well as other, elections.

There is no doubt that state supreme court elections have changed in some ways. Thanks to reports produced by N ew Y ork University Law School's B rennan Center (Goldberg, Holman, and Sanchez 2000; Goldberg, Samis, B ender, and W eiss 2004; Goldberg and Sanchez 2004; Sample, J ones, and W eiss 2007) (Sample, Skaggs, Blitzer, and Casey 2010, 8), we know that spending and advertising in such elections have increased in the aggregate, with candidate fundraising in the decade 2000-2009 more than doubling from $\$ 83.3$ million in the prior decade to $\$ 206.4$ million (Sample, Skaggs, Blitzer, and Casey 2010, 8). However, despite fears expressed in the wake of Republican Party of M innesota v. White, 536 U.S. 765 (2002), which struck down key limitations on what candidates for judicial office could say in the course of their campaigns (i.e., bans on announcing positions on legal or political issues), there is no evidence that the tone of advertising in state supreme court el ections has undergone broad change. The proportion of elections that feature attack-style ads has remained stable since $2002 .{ }^{1}$ The proportion of advertising airings comprised of attack ads, has varied since 2000 but shows no particular pattern; it proportion was actually highest in $2000 .^{2}$

\footnotetext{
${ }^{1} \mathrm{U}$ sing data on campaign advertising assembled by the B rennan Center for 2002 through 2006, M elinda Gann Hall (2011) found that the proportion of elections featuring attack ads had been fairly stable over the period: $11.1 \%$, $16.3 \%$, and $10.6 \%$; for 2008 the corresponding figure is $11.6 \%$.

${ }^{2} \mathrm{~B}$ ased on information appearing in B rennan Center reports or provided to me by staff at the B rennan Center, the percentage of airings that were attack ads for $2000,2002,2004$, and $2006: 38.4 \%, 7.5 \%$ or $9.9 \%, 22.5 \%, 20.0 \%$, and $26.1 \%$; the ambiguity for 2002 reflects that the B rennan Center report shows a percentage as well as providing the data themselves, and my calculation from the data (7.5\%) differs from the summary figure in the report (9.9\%).
} 
M ore relevant for the analysis presented in this article is the role of competitiveness and contestation in such elections, and whether competition is a positive or a negative. Democratic theory would lead one to see competitive elections as a good thing because it would be indicative of an active public debate and this is just as true for judicial elections as for elections to other types of public office (see B onneau and Hall 2009). Ironically, for many observers increased competition in judicial elections is seen as a negative because it leads candidates to do things (raise money, state positions on issues, attack opponents) that are taken to be incompatible with the judicial role. Thus, for proponents of reform, such as retired U.S. Supreme Court justice Sandra Day O'Connor who chairs the O'Connor J udicial Selection Initiative (see Schwartz 2009), increasing levels of competition in elections for judges would be a primary reason to move to alternative systems of judicial selection. ${ }^{3}$

In fact, the evidence regarding increased competition in recent years is mixed. M elinda Gann Hall has examined the question of whether state supreme court incumbents were challenged in elections (both partisan and nonpartisan) over the period 1980 to 2000, and found that the percent challenged grew from about 50 percent at the beginning of the period she examined to 75 percent or more at the end of the period (Hall 2007, 171). ${ }^{4}$ H owever, her analysis did not reveal any clear trends in the competitiveness of elections where challengers entered the race or in patterns competition in open seat elections (id., 175-82). ${ }^{5}$

\footnotetext{
${ }^{3}$ It is worth noting that while the debate is expressed in terms of "judicial elections" generally, the concern has been primarily with state supreme court el ections. In fact the vast majority of research on judicial elections focuses on state supreme courts we know much less about elections to lower courts, either in terms of how those elections are conducted (but see A rbour and M cK enzie 2010) or about the impact of the selection process on what lower court judges actually do when on the bench (but see Huber and Gordon 2004; K ritzer 2007, 462-64).

${ }^{4} \mathrm{H}$ all al so examines retention elections for state supreme court justice, which I omit from my analysis. A spin (2007) has tracked retention elections, covering both state supreme courts and lower courts, for a set of states back to 1964.

${ }^{5}$ In an earlier article, which examined elections between 1980 and 1994, Hall showed that competitiveness in state supreme court elections was actually fairly similar to the competitiveness in elections for the U.S. House of Representatives (Hall 2001, 319)
} 
One possible concern regarding Hall's analysis is the relatively short period, 20 years, she examined. It is possible that the starting point for her research, 1980, represented not the end of a period of stability vis-à-vis challenges to incumbents but either just one point on a longer trend of secular change or a low point in what could be a something of a cyclical pattern. Similarly, it might be that examining a longer period would show changes in the competitiveness of elections that occurred prior to $1980 .^{6}$

In this article I present an analysis of the pattern of competition, both contestation and closeness, in judicial elections over a 64 year period, 1946 through 2009. I focus specifically on seats up for election. In the discussion that follows I examine whether the elections for those seats were contested and how close the elections were. Through this analysis, I seek to answer the closely related questions of whether elections are more likely to be contested in recent years and whether elections are more likely to be competitive.

\section{DATA}

For this study I sought to assemble data on every state supreme court election conducted on a partisan or nonpartisan basis since 1946, including primary elections, primary run-offs, and general elections; ${ }^{7}$ these elections filled a total of 1,863 seats on state supreme courts. ${ }^{8}$ The sources for these data varied from state to state. For recent elections, virtually all of the needed information was available online from state election office websites. For earlier elections, some states routinely published detailed election reports which I was able to obtain from one of several

\footnotetext{
${ }^{6}$ D ubois $(1980,50)$ provides some data on competitiveness of state supreme court elections for the period 19481974. However, his analysis excludes southern states and primary elections. M oreover, it does not control for the presence of an incumbent in the election.

${ }^{7}$ Texas and Oklahoma have separate courts of last resort for criminal and noncriminal cases; for those states, I have included elections for both courts.

${ }^{8}$ If three seats are up for election, for purposes of this paper I count that as three elections.
} 
libraries. For other states the necessary information was provided to me by state election offices. For still other states, the information had been shipped off to state archives, and to obtain the information I sought, it was necessary to arrange to have someone go to the archive and retrieve the information on my behalf. For a few primary elections, I relied upon newspaper reports of overall election results. ${ }^{9}$

For those seats with contested primaries but an uncontested general election, I employ information from the primary election. If there are both primary and general elections for a seat, I use as my indicator of closeness the election with the closest vote involving the incumbent (or the victor in the case of an open seat election). ${ }^{10}$ States with multi-seat elections in which candidates did not run for specific seats (i.e., if two seats were contested, the top two vote getters win), what I will label "unassigned multi-seat elections", raise some specific issues. First, how should one handle the situation where the number of candidates is less than twice the number of seats (i.e., three candidates running for two seats)? In those elections, if there is one fewer candidates than twice the seats, I treat the top vote getter as unopposed; so, for example if there are three seats and five candidates, one seat is deemed unopposed and two as opposed (with the top vote getter assigned to the unopposed seat). The second issue is how to determine how close the elections are in unassigned, multi-seat elections? I adopt the convention of pairing first the highest and lowest vote getters, then the second highest and second lowest, on down. For

\footnotetext{
${ }^{9}$ The newspaper reports were usually unofficial and often provided less than complete results. However, given the way I have categorized election results, it is unlikely that complete returns would shift an election from one category to another.

${ }^{10}$ In a handful of elections, the incumbent was defeated in the primary election, and the winner of the primary went on to face opposition in the general election. In those cases, I employed the results of the primary election in my analysis. In partisan election states where the nonincumbent loser in the general election had run in a contested primary election, I ignore the primary results involving the general election loser even if it was closer than the general election.
} 
unassigned multi-seat partisan elections, I pair the highest D emocrat with the lowest Republican, the highest Republican with the lowest Democrat, and then the middle pair or pairs. ${ }^{11}$

One final issue needs to be noted. Some competition is best described as symbolic rather than real. For example, while through the 1940s, 50s, and into the 60s, elections in most of the South were one-party affairs, there were a small number of state supreme court elections in which Republicans did appear on the ballot. To say that such candidates did not stand a chance of winning is an understatement: usually they received less than 15 percent of the vote. $\mathrm{M}$ ore recently, some of the southern states have become essentially one-party Republican in state supreme court elections, but in a number of elections uncontested by Democrats, Libertarians have entered the general election to challenge the Republican candidate; typically the Libertarians get at most 25 percent of the vote. Because of this phenomenon, ${ }^{12}$ I have chosen not to focus simply on contested versus uncontested elections, but rather to classify elections into five categories: uncontested, symbolically contested (winner got $75-99 \%$ of the vote), noncompetitive (winner got 60-74\%), competitive (50-59\% for the winner), ${ }_{1}^{13}$ and incumbent defeats; ${ }^{14}$ the latter category applies only when there was an incumbent running for reelection. ${ }^{15}$

\footnotetext{
${ }^{11} \mathrm{U}$ ndoubtedly there are other ways that this could be handled. However, given that relatively few states have unassigned, multi-seat elections, it is exceedingly unlikely that adopting a different approach would have a significant impact on the results that I report in this article.

${ }^{12}$ In a number of the elections involving what I label "symbolically contested" general elections there was a much closer primary election, and that primary election is used for the statistical analysis.

${ }^{13} \mathrm{I}$ include in this category elections where the ultimate winner was not the top vote-getter in a first round (usually a primary) but did win the run-off. Some readers might question my categorization, and prefer to limit "competitive" elections to those in which the winner received 55 percent or less of the vote. I have repeated the analysis using the categorization; the broad patterns that I report remain the same.

${ }^{14}$ In computing the percentage, I focus on the top two vote-getters; for example, if there were three candidates in a primary, getting $45 \%, 40 \%$, and $15 \%$ respectively, I take the top two and recomputed the percentage focused on those top candidates. In this case, that percentage would be $45 / 85=52.9 \%$. M y rationale for this approach is that it is the closeness between the top two candidates that matters to the winner.

${ }^{15}$ One other minor issue concerns retention elections. In this article I am not examining retention elections. There are two states (Utah and M ontana) that have a system of nonpartisan elections with the provision that if an incumbent is not opposed, the el ection becomes a retention vote. I have treated such elections as unopposed nonpartisan elections.
} 


\section{ANALYSIS}

The analysis that follows is presented mostly in the form of area graphs, all but one of which divide the vertical space proportionately among the three to five categories being considered. One can think of each graph as representing a series of pie charts or as a stacked bar vertical bar graph that has been run together and smoothed. The advantage of these graphs is that it allows one to quickly see how the distribution among the categories has shifted over time. The disadvantage is that it takes a bit of effort to estimate a specific percentage other than for the category shown at the bottom of the graph. In all of the area graphs (except Figure 2), the topmost area (always in light gray) represents the proportion of elections that were uncontested. The solid black area just below the top area represents the proportion of elections that were symbolically contested (the winner received at least 75 percent of the vote). The middle area (shown in white) represents the proportion of noncompetitive elections in which the winner received 60-74 percent. For elections involving incumbents, the dark gray area at the bottom of the graph represents the proportion of elections in which the incumbent lost and the medium gray area just above represents the proportion of elections that the incumbent won with less than 60 percent of the vote. For open-seat elections, the bottom area is shown in medium gray and represents the proportion of elections won with less than 60 percent of the vote. ${ }^{16}$

M ost state supreme court el ections take place in even-numbered years. In a small number of states some or all such elections are held in odd-numbered years. For purposes of analysis and presentation, I have grouped el ections occurring in odd-numbered years with the prior year. For open-seat elections, I have grouped the elections into four year sets, labeled with the year of the

\footnotetext{
${ }^{16}$ In computing all of these percentages, I focus only on the top two vote-getters.
} 


\section{FIGURE 1: CONTESTATION AND COMPETITIVENESS, ALL ELECTIONS}

\section{INVOLVING INCUMBENTS}

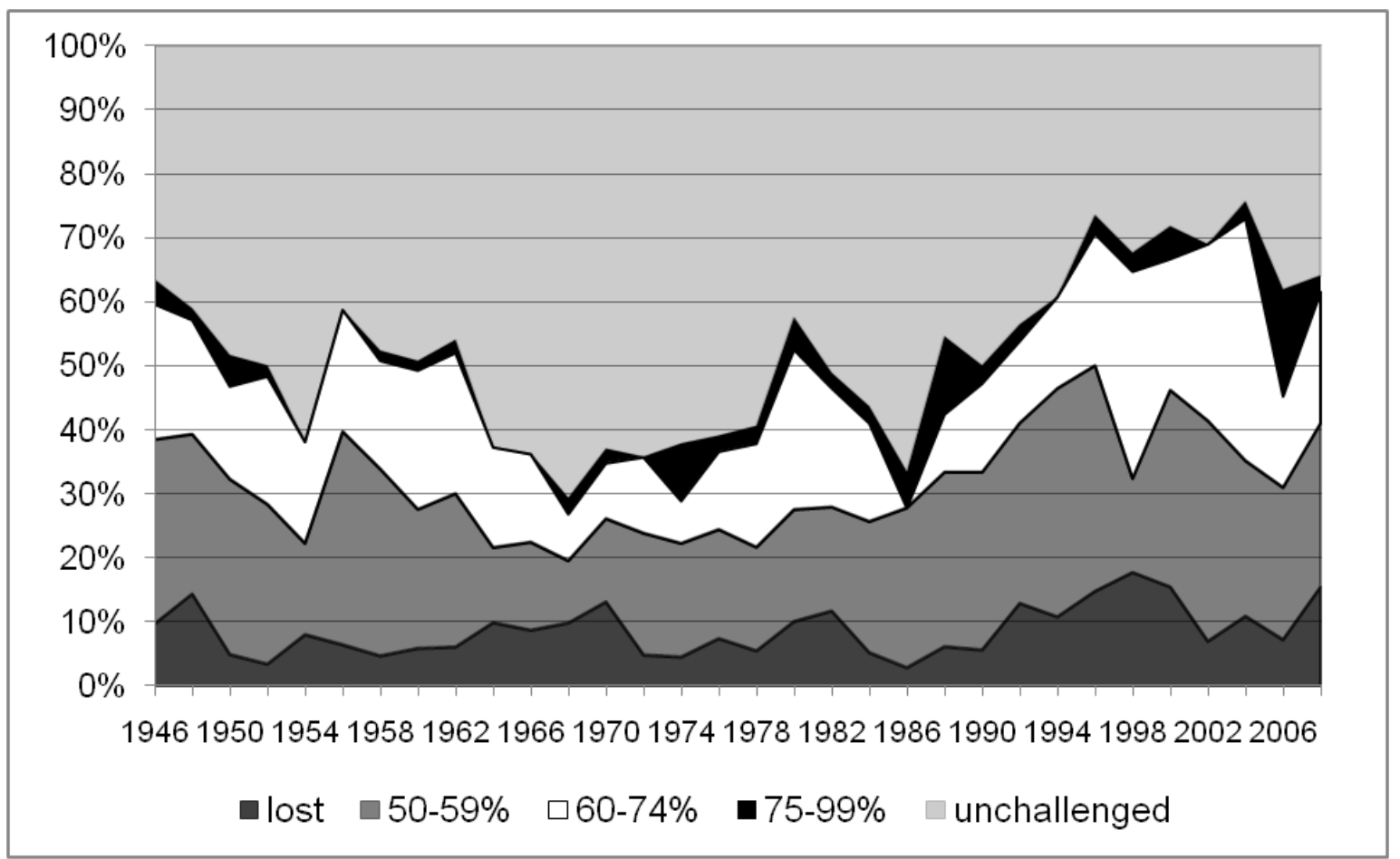

presidential election; hence, the data point for open seat elections labeled 1948 captures the judicial elections that occurred from 1946 through 1949.

\section{A. Elections Involving Incumbents}

Figure 1 shows the overall pattern of contestation and competitiveness in state supreme court elections involving incumbents since 1946. To avoid clutter, Figure 1 and subsequent figures do not show the number of elections upon which the percentages reflected in the figures are based; I include this information in A ppendix A (Table A 1). For some of the figures the number of elections reflected in a data point is quite small, and those figures need to be treated with caution. 
One can read Figure 1 by looking at a particular year and estimating the percentage for that year. For example, for 1990 the figure shows that in ${ }^{17}$

- $7 \%$ of the elections incumbents lost (dark gray area)

- $26 \%$ of the election incumbents won with less than $60 \%$ of the vote (medium gray area)

- $15 \%$ of the elections incumbents won with $60-74 \%$ of the vote (white area)

- $2 \%$ of the elections incumbents won with $75 \%$ or more of the vote (black area)

- $40 \%$ of the elections incumbents were unopposed (light gray area)

As the figure shows, there is a lot of year-to-year variation; my interest is in patterns of change of a period of years.

A first point to note is that while Figure 1 shows some are shifts, they are generally relatively subtle as opposed to striking. There is no clear pattern in the likelihood of incumbents being defeated (the bottom-most area shown in dark gray), although arguably there is a slight increase starting around 1988. If one combines elections where incumbents lost with those which I have label ed as competitive (i.e., combine the bottom two areas shown in medium and dark gray), there does appear to be some pattern of increase starting in the 1970s. A nd while the graph shows a decrease in the proportion of incumbents who were unchallenged (the top-most area in the figure shown in light gray), one also sees that there was a period when the likelihood of being unchallenged actually increased, and while percent unchallenged in the current period is lower than earlier periods, how much lower depends on what one chooses to use as a baseline.

One obvious question is whether the pattern of change is random or reflects systematic differences. To assess this, question, I compared the eight years starting in 1946 (the "early period", n=293) with the eight years ending in 2009 (the "late period", n=185), and I collapsed the first two categories (elections where the incumbent lost and elections where the incumbent

\footnotetext{
${ }^{17} \mathrm{~A}$ spreadsheet showing the detail for each of the figures is available at https://netfiles.umn.edu/users/kritzer/www/research/J ELS2010-J udicialElectionFigures.xlsx.
} 
received less than 60 percent of the vote) and the last two categories (where the incumbent was unopposed or won with 75 percent or more of the vote. ${ }^{18} \mathrm{~A}$ simple goodness-of-fit (GOF) chi square test for all elections involving incumbents shows that the difference between the early and late periods is not statistically significant $\left(\bullet^{2}=3.34, d f=2, p=.188\right)$. One issue with the use of the simple chi square test is that it assumes that all observations are statistically independent, something with is clearly untrue given that there are multiple elections from a given state. However, the impact of this kind of nonindependence tends to inflate the statistical significance of the tests because the practical effect of such dependence is that one has less information than the test assumes. Hence, when the chi square fails to achieve statistical significance, one can be confident that an adjustment of the clustering of observations within states would not change the conclusion from nonsignificance to statistically significant. ${ }^{19}$

What about the dip in the middle of the period? To assess whether this introduces a statistically significant difference, I created a ten-year "middle" period covering 1966 through 1975; the GOF chi square test using three periods is statistically significant $\left(\bullet^{2}=35.48, \mathrm{df}=4\right.$, $p<.001)$. In order to adjust for the nonindependence problem discussed in the previous paragraph, I used Stata to fit a simple multinomial logistic regression model with dummy variables for the late and middle periods (the early period served as the reference category) obtaining robust standard errors with clustering on state, and did a general linear hypothesis test of the four parameters. The resulting Wald-test chi square is 25.86 ( $4 \mathrm{df}, \mathrm{p}<.001)$, confirming that the dip in

\footnotetext{
${ }^{18}$ I also ran the chi square tests without collapsing the five categories, and the results did not change, although the number of observations in the "incumbent defeated" and "75-99\% categories was very small for some of the later figures discussed in the following pages. Generally, where the cell frequencies are low, I also ran Fisher's Exact test; the significance levels were virtually identical to what I found for the GOF chi square test, and hence I do not report the significance levels for Fisher's Exact.

${ }^{19} \mathrm{I}$ in fact ran the tests that adjusted for nonindependence for all of the tests reported as nonsignificant and the adjusted tests were also nonsignificant.
} 


\section{FIGURE 2: DISTRIBUTION OF ELECTION TYPES}

(a)

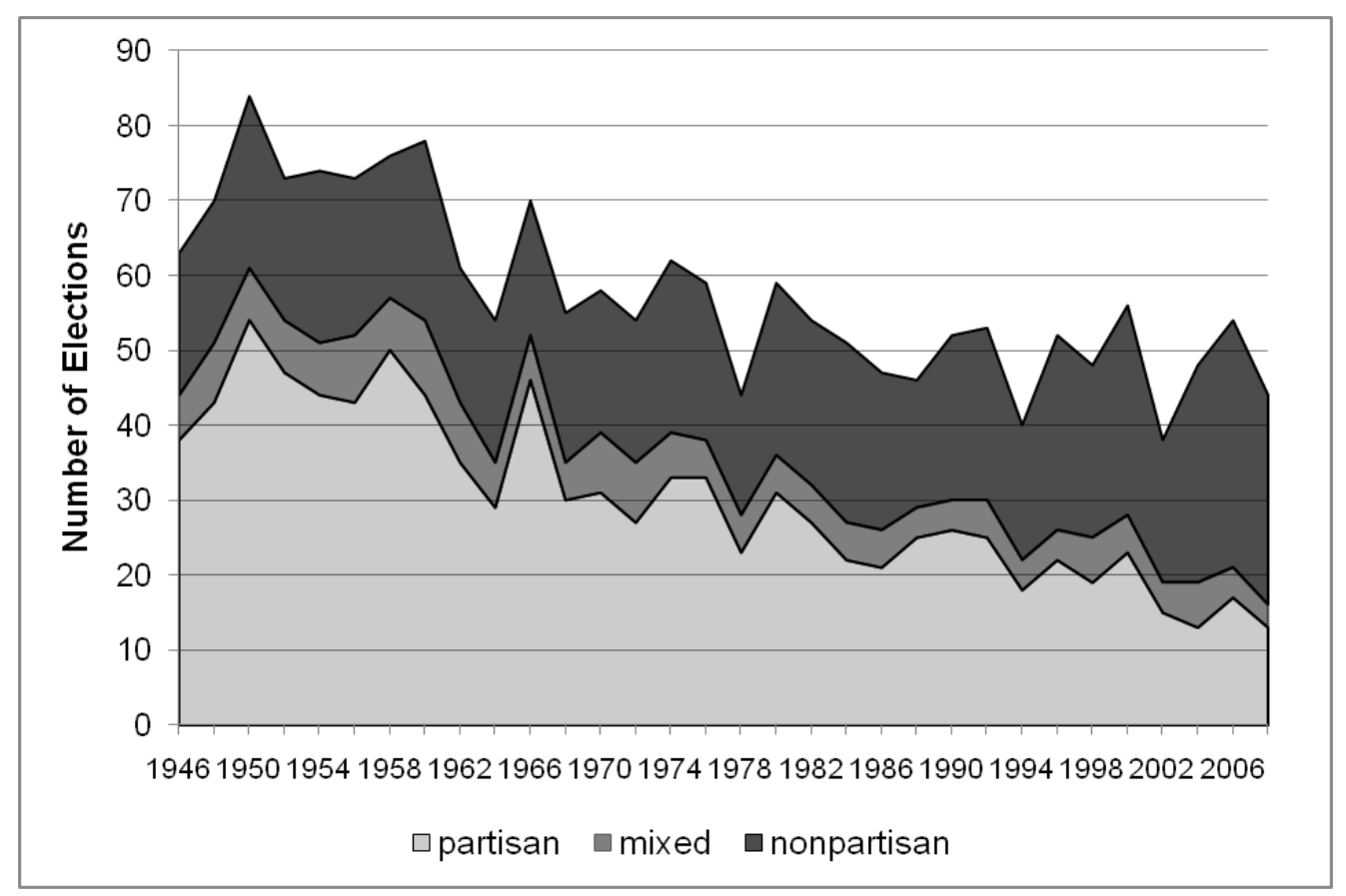

(b)

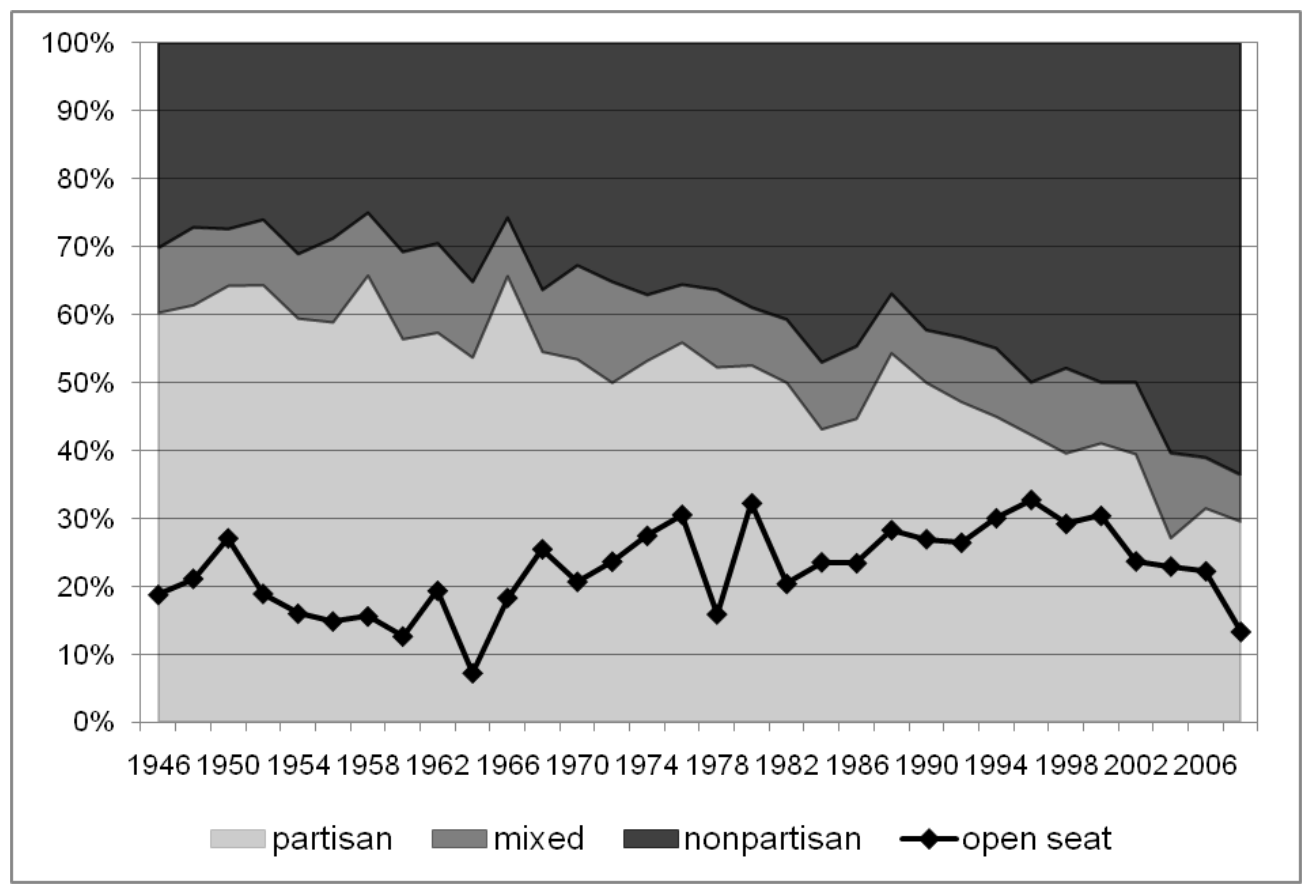


competition during the period 1966-75 reflected a statistically significant difference from the early and late period.

W hile the middle period does involve a period of lowered competition, exactly what accounts for that shift is unclear. One problem with interpreting this overall pattern is that over the 64 year period shown in Figure 1, there have been major changes in the distribution of types of elections. While in the 1940s the majority of elections were (at least nominally) partisan, by the 2000 s a majority were nonpartisan. A Iso, as shown in Figure $2 \mathrm{a}$, there has been a substantial decline in the number of elections, although this is largely due to a decline in the number of partisan elections (the bottom area shown in light gray in the figure); the number of nonpartisan elections (the top area show in dark gray in the figure) has remained relatively stable). ${ }^{20}$ Figure 2a shows a small group of elections designated as "mixed" (the middle area shown in medium gray); these are elections in Ohio, M ichigan, and A rizona where nominations are (or wereA rizona switched to the "merit" system in 1974) made by parties, through primaries in Ohio and A rizona, and at conventions in M ichigan. However, while the parties do the nominating, the general election ballot does not show the party affiliation of the candidates. Because of the shifting distribution of election types as shown in Figure $2 \mathrm{~b}$ (a decreasing proportion are partisan and an increasing proportion are nonpartisan), it is paramount to look separately at partisan and nonpartisan elections to begin to understand the nature of changes competition and competitiveness that may have occurred. Figure $2 \mathrm{~b}$ also shows a line tracing the percentage of state supreme court seats without an incumbent running; there appears to be a slight increase

\footnotetext{
${ }^{20}$ This stability does mask some changes. A number of states that employed nonpartisan elections in 1946 have since switched to "merit" systems for selecting and retaining members of the state supreme court. A the same time, about the same number of states that previously used partisan elections have switched to nonpartisan elections (some formerly partisan election states now use the "merit" system). Figure B 1 in A ppendix B shows the evolution of selection systems among those states that used partisan, mixed, or nonpartisan elections in 1946.
} 
FIGURE 3: CONTESTATION AND COMPETITIVENESS, NONPARTISAN ELECTIONS INVOLVING INCUMBENTS

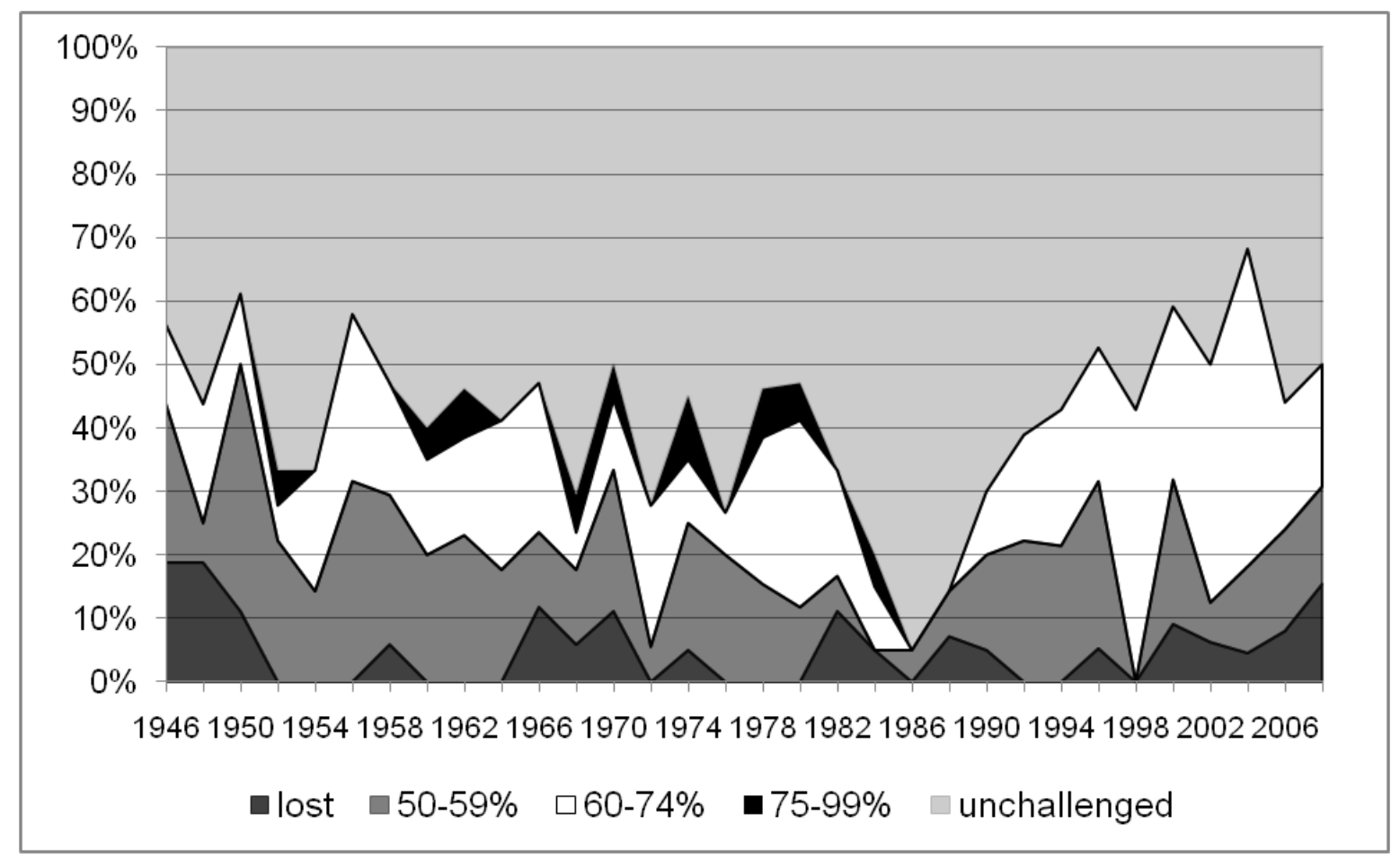

over time, with under 20 percent (18.2) up through 1970, rising to about 25 percent (25.4) after 1970.

Figure 3 replicates Figure 1 but for nonpartisan elections only, not including the mixed elections (which group more appropriately with partisan elections given the active and explicit role of parties in the process). Figure 3 shows some decline in the percentage of nonpartisan elections involving an unchallenged incumbent (the top most area in the graph). However, the decline in unchallenged incumbents is not accompanied by an increase in competitive elections (or incumbent losses); the increase comes in the noncompetitive elections. The difference between the early and late periods does achieve statistical significance $\left(\mathrm{GOF} \cdot{ }^{2}=8.48, p=.014\right.$; Wald $\bullet^{2}=7.27, p=.026$ ), although the pattern is not particularly strong. 


\section{FIGURE 4: CONTESTATION AND COMPETITIVENESS, PARTISAN AND MIXED ELECTIONS INVOLVING INCUMBENTS}

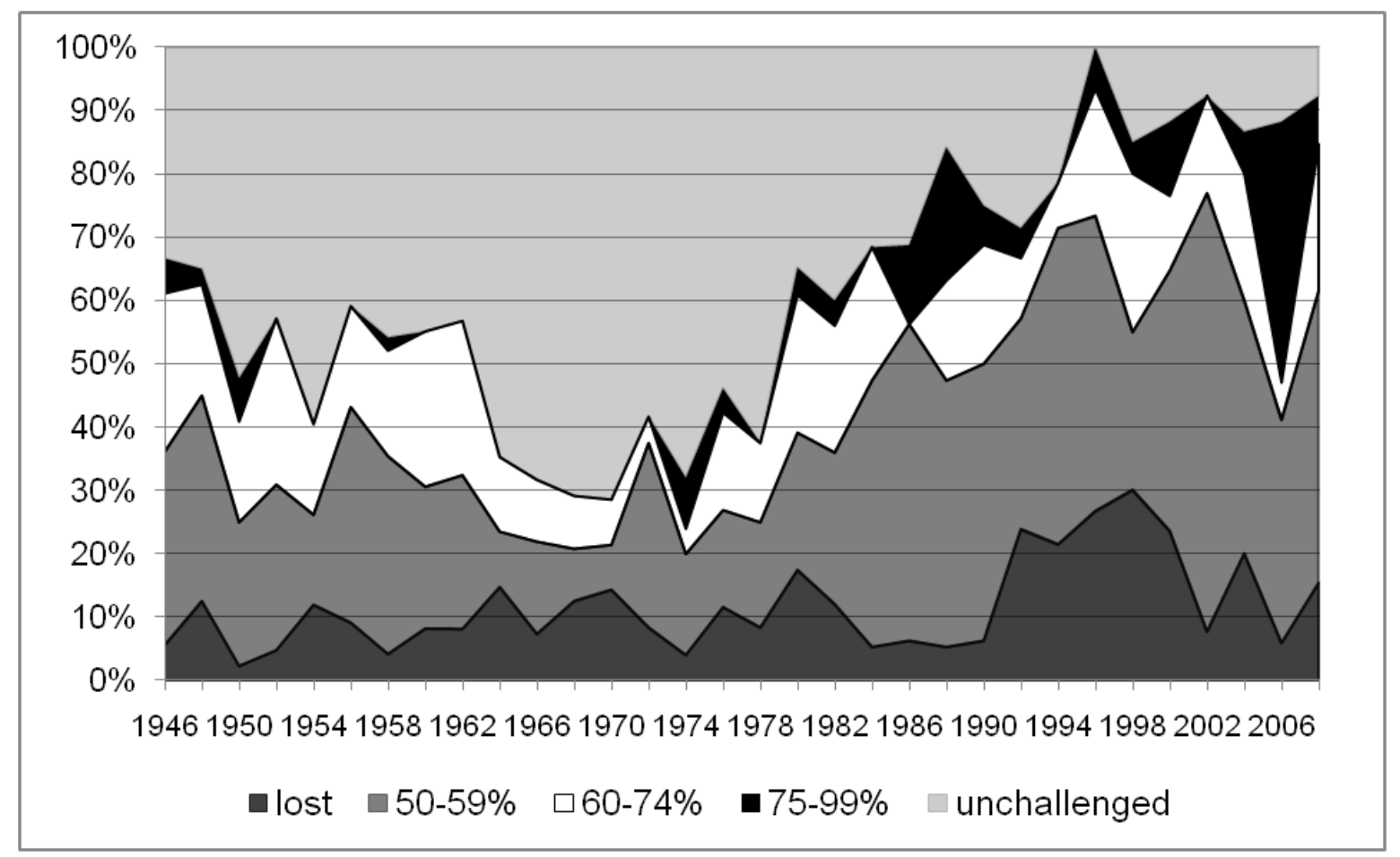

Figure 4 provides the same information for partisan and mixed elections. Here one sees initially an increase in unchallenged incumbents (the top, light gray area in the figure) into the 1970s followed by a sharp decline with a concomitant increase in competitive elections and incumbent losses (the bottom two areas in dark and medium gray), al though competitiveness seems to have declined in the most recent years. Simple GOF chi square tests, either comparing just early and late periods, or including the middle period $1966-75,{ }^{21}$ achieve statistical significance $\left(\bullet^{2}=11.02, p=.004\right.$, comparing early and late; $\bullet^{2}=41.86, p<.001$, comparing three periods), and the Wald test using multinomial logistic regression with clustering is statistically significant for the three period model $\left(\cdot^{2}=25.12, p<.001\right)$, but does not quite achieve statistical

\footnotetext{
${ }^{21}$ If one were designating a middle period based purely on Figure 4, one would probably extend it back to start in 1964, and possibly extend it forward to 1979.
} 
significance for the two period model $\left(\cdot^{2}=5.58, p<.061\right)$. This suggests that understanding the decline in the middle period is important.

Initially, this pattern may seem surprising given that one might expect parties to make an effort to find and support candidates. However, one must keep in mind that a substantial number of the partisan elections are from states in the formerly one-party South and there have been huge political changes in that region over the period under consideration. The change in the South suggests looking separately at southern and nonsouthern states that use partisan (and mixed) elections.

Figure 5 shows the pattern separately by region with the South defined as A labama, A rkansas, Florida, G eorgia, Louisiana, M ississippi, N orth Carolina, Tennessee, and Texas. ${ }^{22}$ For the South (Figure 5a) there are very substantial changes, both in the decline of unchallenged incumbents (the top area) and in the increase in competitive elections and incumbent losses (the bottom two areas). In the most recent years, there is an increase in symbolic challengers (shown in black just below the top area in light gray that represents the proportion of elections involving unchallenged incumbents). ${ }^{23} \mathrm{~A}$ ll of the statistical tests of differences, both the two and three period tests, and the GOF and W ald tests are strongly significant. ${ }^{24}$ In contrast, in the N onsouth, there was a decrease in unchallenged incumbent elections (the top most area) but it occurred prior to 1980; the pattern of competitive elections and incumbent losses shows no pattern of

\footnotetext{
${ }^{22}$ For purposes of these figures, I have grouped the border states of K entucky and Oklahoma with the N onsouth states; grouping K entucky (which switched to nonpartisan elections in 1976) and Oklahoma (which switched to the "merit" system starting in 1968) with the southern states makes little or no difference. Virginia and South Carolina are no listed above because they do not use partisan or nonpartisan elections for selecting justices for their supreme courts.

${ }^{23}$ In assessing change in the South one also has to keep in mind that in the most recent years only A labama, L ouisiana, and Texas retain the partisan election system. Tennessee and Florida have shifted to "merit" systems (in 1994 and 1978 respectively; Florida used nonpartisan elections from 1972 to 1976), and A rkansas (2002), Georgia (1983), M ississippi (1996), and North Carolina (2004) all switched to nonpartisan elections. However, if I drop from Figure 5a the states that abandoned partisan elections prior to 2000 (Florida, Georgia, M ississippi, and Tennessee), the pattern remains unchanged.

${ }^{24}$ The two and three period GOF chi squares are 35.76 and 76.75 respectively; the corresponding $W$ ald chi squares from multinomial logistics regressions with clustering by state are 16.63 and 40.78 (for all four $p<.001$ ).
} 
FIGURE 5: CONTESTATION AND COMPETITIVENESS, PARTISAN ELECTIONS INVOLVING INCUMBENTS BY REGION

(a) SOUTHERN STATES (AL, AR, FL, GA, LA, MS, NC, TN, TX)

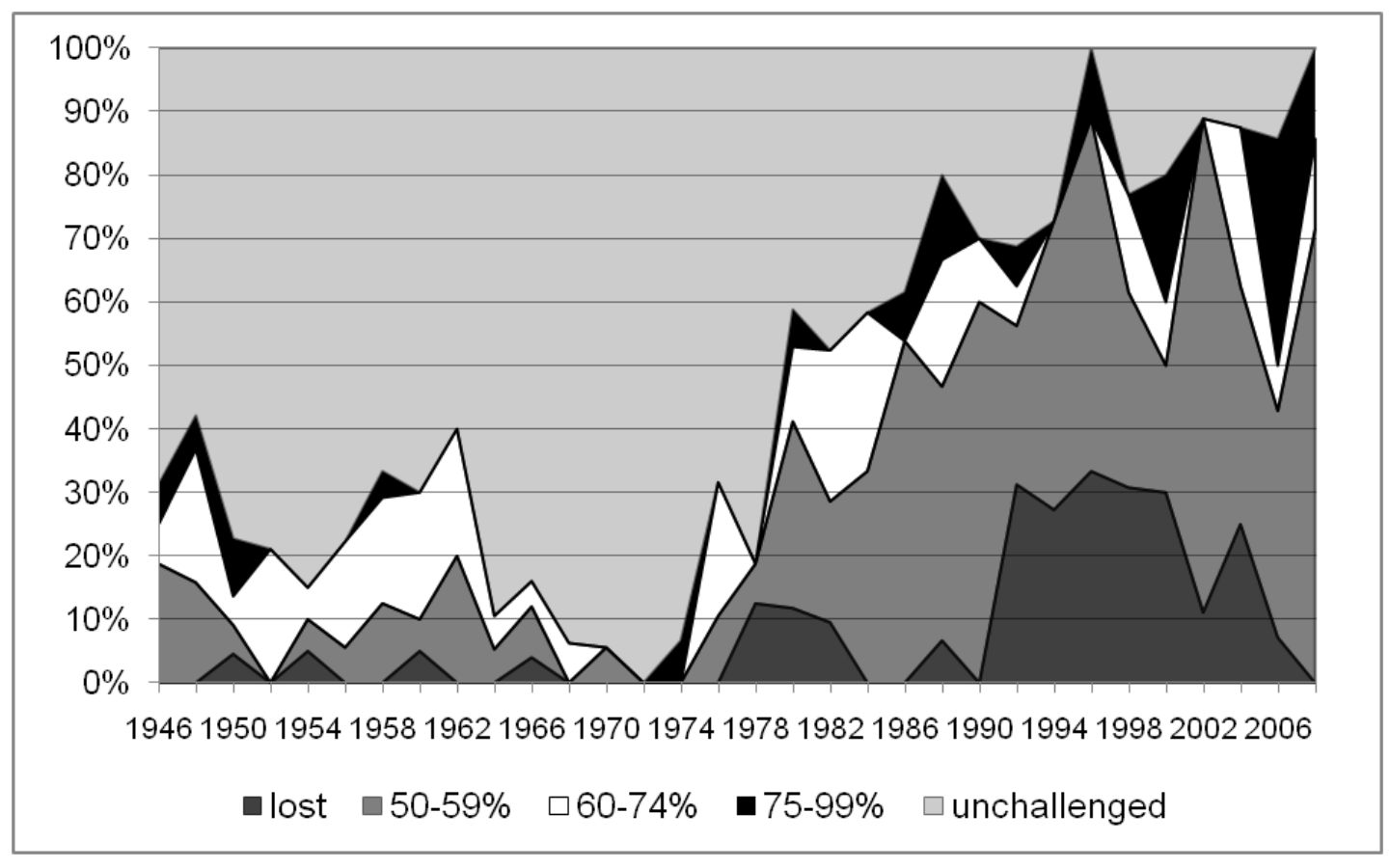

(b) NONSOUTH STATES

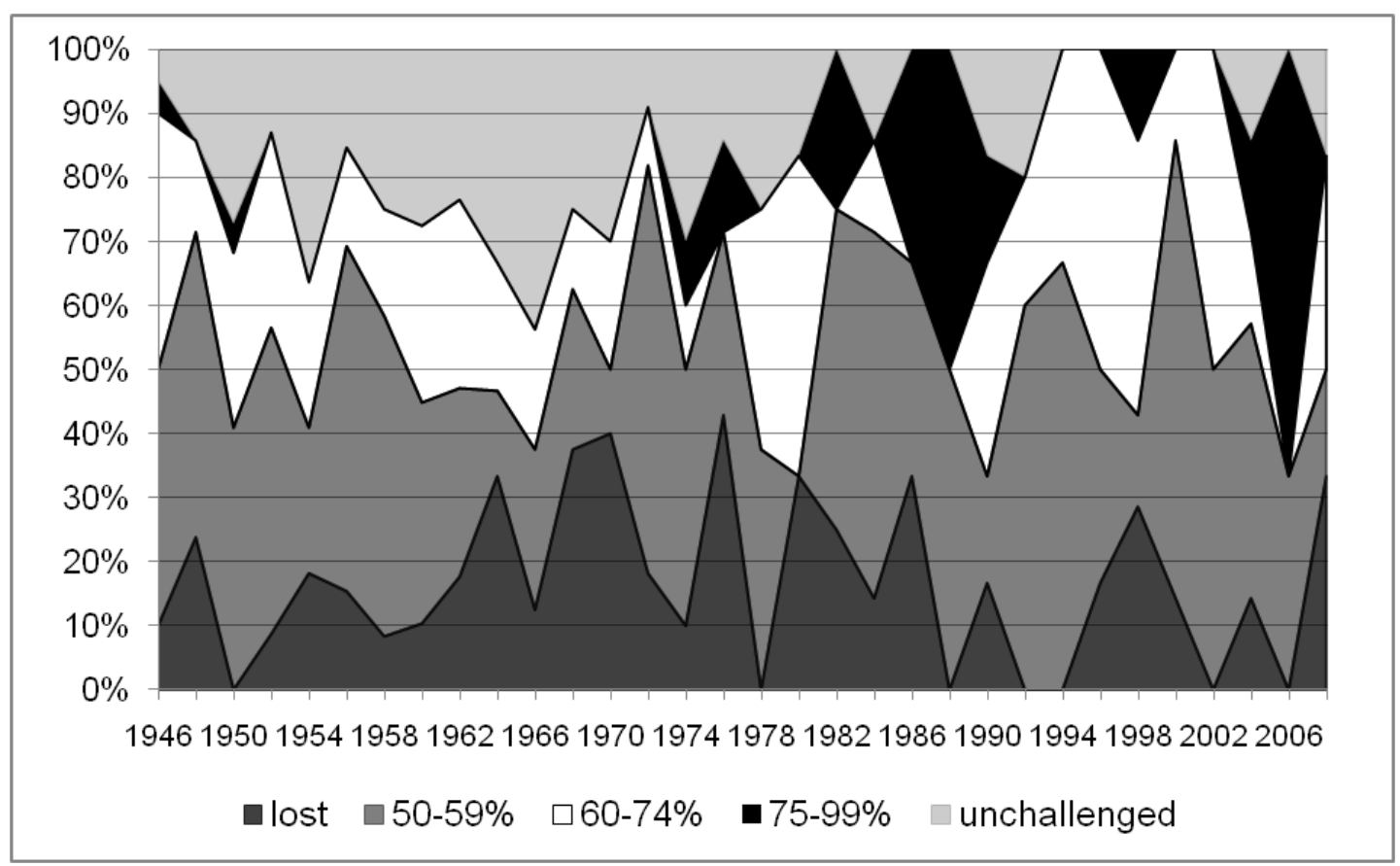


change during the period under consideration. Neither the two period nor the three period GOF chi squares approach statistical significance $\left(\bullet^{2}=0.61, p=.738 ; \bullet^{2}=5.40, p=.248\right) .{ }^{25}$

How might one account for the pattern in the South? The initial decline in competition may have been in response to the perceived threat to the southern "way of life" created by legal challenges to segregation that started in the 1950s and peaked in the 1960s. Then, with the increase in competition coming as the South transitioned to a two party system (see Black 2004, 1002-07) elections to the state supreme courts started to become competitive. The marginal decline in the most recent years may be due to the overwhelming dominance of the Republican Party in many southern states. This is of course speculative, but it is consistent with the timing of both the drop in competition around the 1964 election between Lyndon J ohnson and Barry Goldwater (and which came soon after the passage of the landmark 1964 Civil Rights Act) in which southern states felt particularly challenged vis-à-vis maintaining segregation, and with the growth in competition starting around 1980 as the Republican party began to gain substantial strength state-level contests in the southern states with the election of Ronald Reagan.

To summarize the pattern of change for el ections involving incumbents, the major change is concentrated in southern states with partisan elections. In nonpartisan elections and in partisan (and mixed) elections outside the South there have been at most relatively modest shifts, largely

\footnotetext{
${ }^{25}$ Two questions that might be raised about the pattern in Figure 5 a are (1) whether it is driven by changes in which states in the South employed partisan elections, and (2) whether it was driven by one or two states. As for the first question, all of the states were present for the first two periods, and hence the drop during the middle period does not reflect a change in the states represented in Figure 5a. A rkansas, Florida, Georgia, M ississippi, and Tennessee abandoned partisan elections before the start of the late period; however, restricting the analysis to the remaining states (A labama, L ouisiana, N orth Carolina, and Texas) produces the same pattern, and the pattern shows statistically significant shifts over time (GOF $\left.\cdot^{2}=49.77, p<.001\right)$. As for the second question, in the late period, Texas provides almost 26 of the 38 elections, so an obvious question is whether Texas is driving the results. Separate tabulations for Texas and for the other states as a group (A labama, L ouisiana, and N orth Carolina) show that the pattern holds for both Texas and the other states, and that the pattern of change is statistically significant for both (GOF $\cdot^{2}=29.06, p<.001$ for Texas and GOF $\cdot^{2}=27.50, p<.001$ for the other three states). N ote that the sample sizes here were too small to apply the multinomial logit analysis.
} 
a decline in the number of uncontested elections. However, that decline has not translated into an increase in competitive elections.

\section{B. O pen Seat Elections}

As shown in Figure $2 b$, in most years well under 30 percent of seats up for election did not have an incumbent seeking to retain his or her position; consequently there are many fewer open seat elections for state supreme courts than there are elections involving incumbents. In part this is the normal pattern of incumbents seeking reelection, but it also reflects the fact that in many states that ostensibly elect the members of the state supreme court, midterm vacancies are filled through an appointment process. Cutting the other way are three states (Illinois, $\mathrm{N}$ ew M exico, and Pennsylvania) that rely on retention elections to retain incumbents but which require a partisan election when a vacancy occurs. ${ }^{26}$ During the period in question there were 1,449 elections (seats) involving incumbents but only 414 open seat elections including three in which the incumbent had sought reelection but were not renominated at party nominating conventions. ${ }^{27}$ Because of the much smaller number of elections, I have grouped elections into four year intervals in the following figures; the year shown in the figure includes the two years prior plus the one year after (e.g., 1948 covers elections from 1946 through 1949). A lso, because there are by definition no incumbent defeats in such elections, the bottom-most area represents what I have labeled competitive elections (and is still shown in medium gray).

Figure 6 shows the pattern for all open-seat elections. There is a slight increase in the likelihood of the winner receiving less than 60 percent of the vote (the bottom most area shown

\footnotetext{
${ }^{26}$ In some states requiring such elections, the governor can appoint someone to fill the seat until the election. In a number of cases, the governor appointed someone who pledged not to run in the election which insured an open seat election. In others, the appointee ran for the seat, and I group those elections with elections involving an incumbent. ${ }^{27}$ One of the open seat elections was a last minute vacancy which was conducted entirely as a write-in election; it is omitted from the analysis. T wo of the el ections where incumbents lost at party conventions (both in Tennessee), the party's nominee was unopposed in the subsequent election; those two elections are also omitted from the analysis.
} 
FIGURE 6: CONTESTATION AND COMPETITIVENESS, ALL OPEN SEAT ELECTIONS, 1946-2009

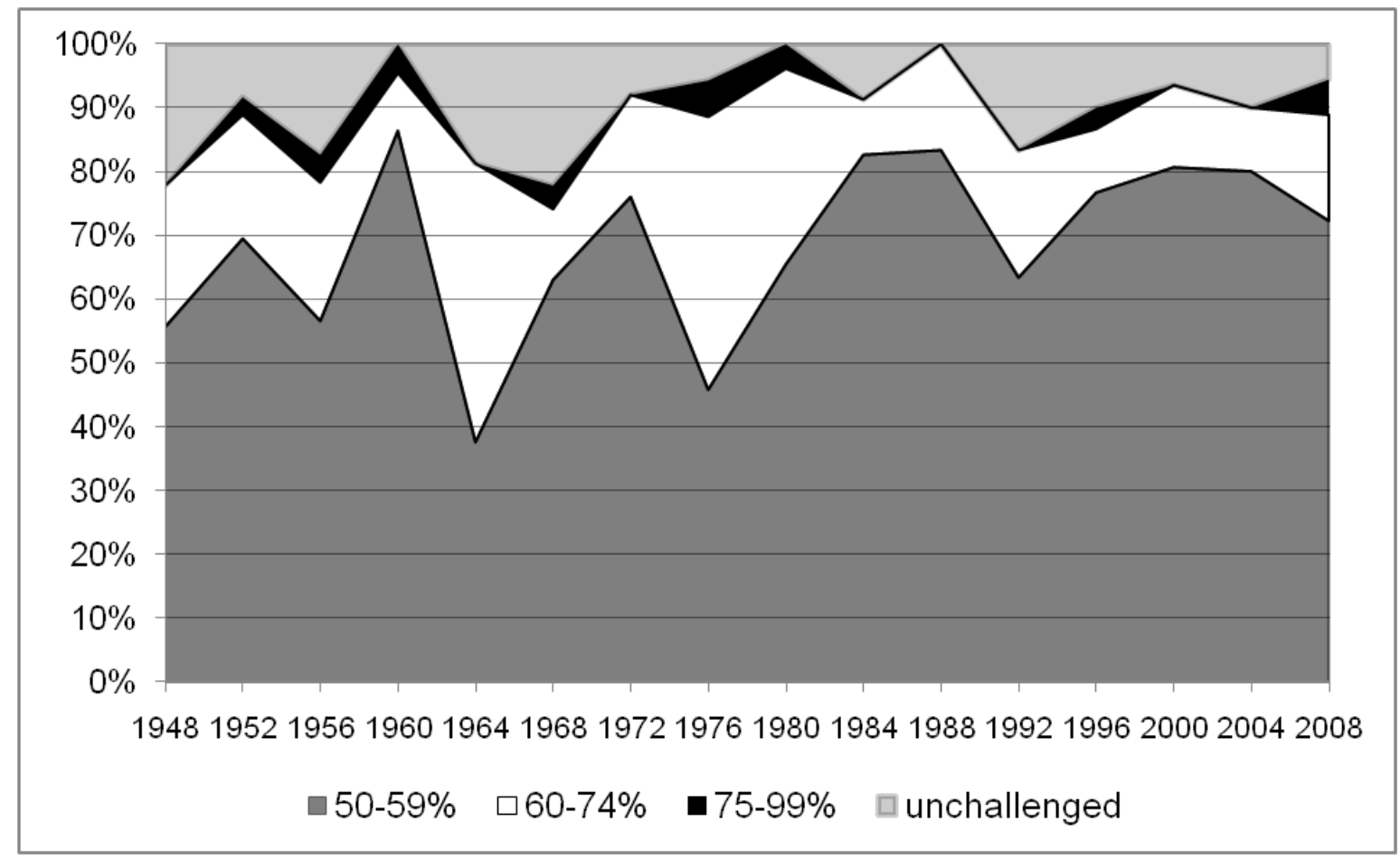

in the figure), with that increase coming from both uncontested elections and noncompetitive elections. There may be a slight dip in the proportion of elections that were competitive during the 1960s. However, comparing the early and late periods does not reveal any statistically significant change ( $\left.\mathrm{GOF} \cdot{ }^{2}=1.80, p=.406\right)$. A s before, we need to look separately at nonpartisan and partisan plus mixed elections.

Figure 7 shows separate patterns for the two broad types of elections. While the patterns appear to differ, we need to treat those differences with caution because GOF chi square tests for examining change over time for each of these two subsets generally fail to achieve statistical significance. For nonpartisan elections, while the percentage of elections that are competitive is greater than it was during the earliest years shown, the period of highest competitiveness appears 
FIGURE 7: CONTESTATION AND COMPETITIVENESS, OPEN SEAT ELECTIONS CONTROLLING FOR ELECTION TYPE

\section{(a) NONPARTISAN ELECTIONS}

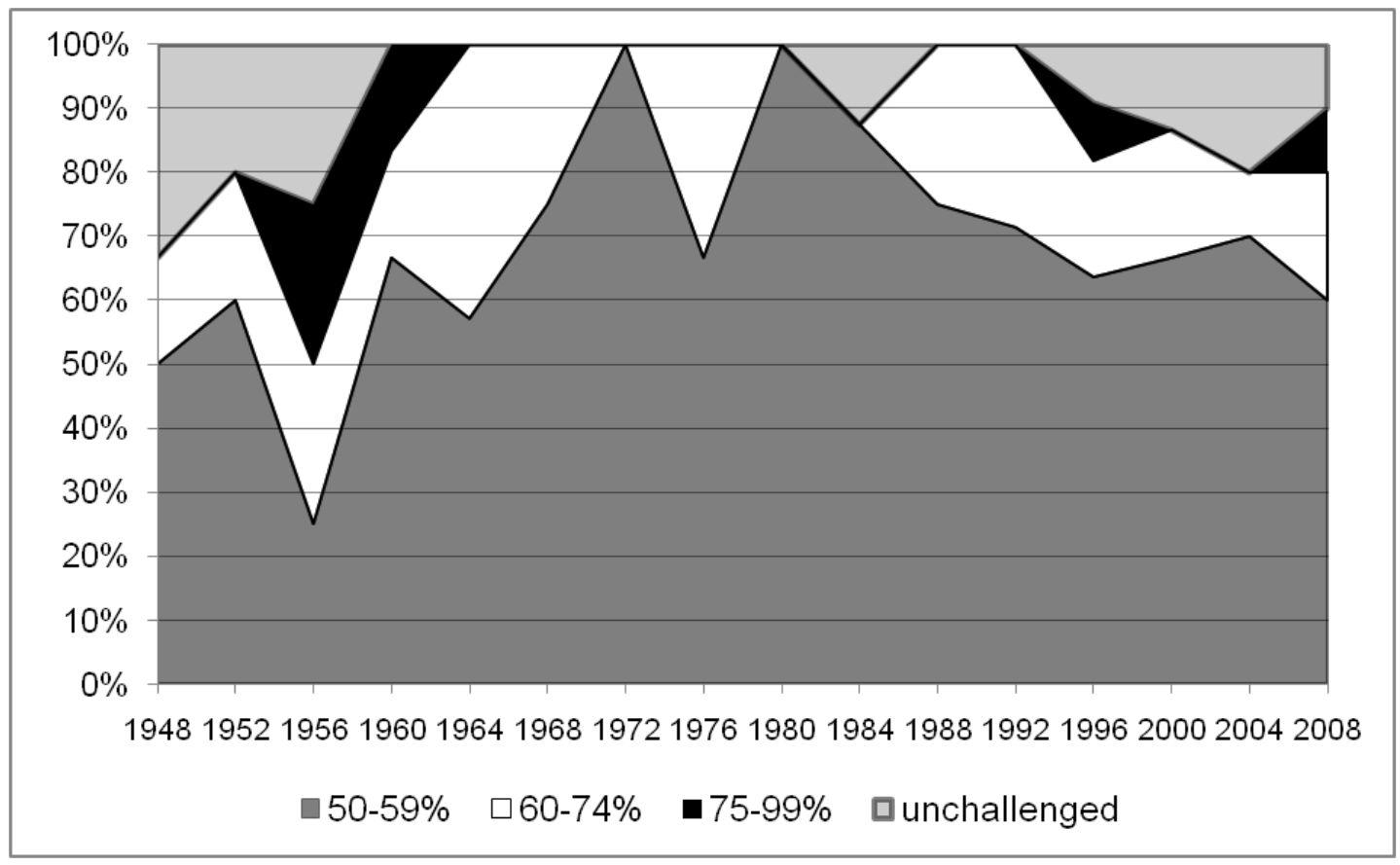

(b) PARTISAN AND MIXED ELECTIONS

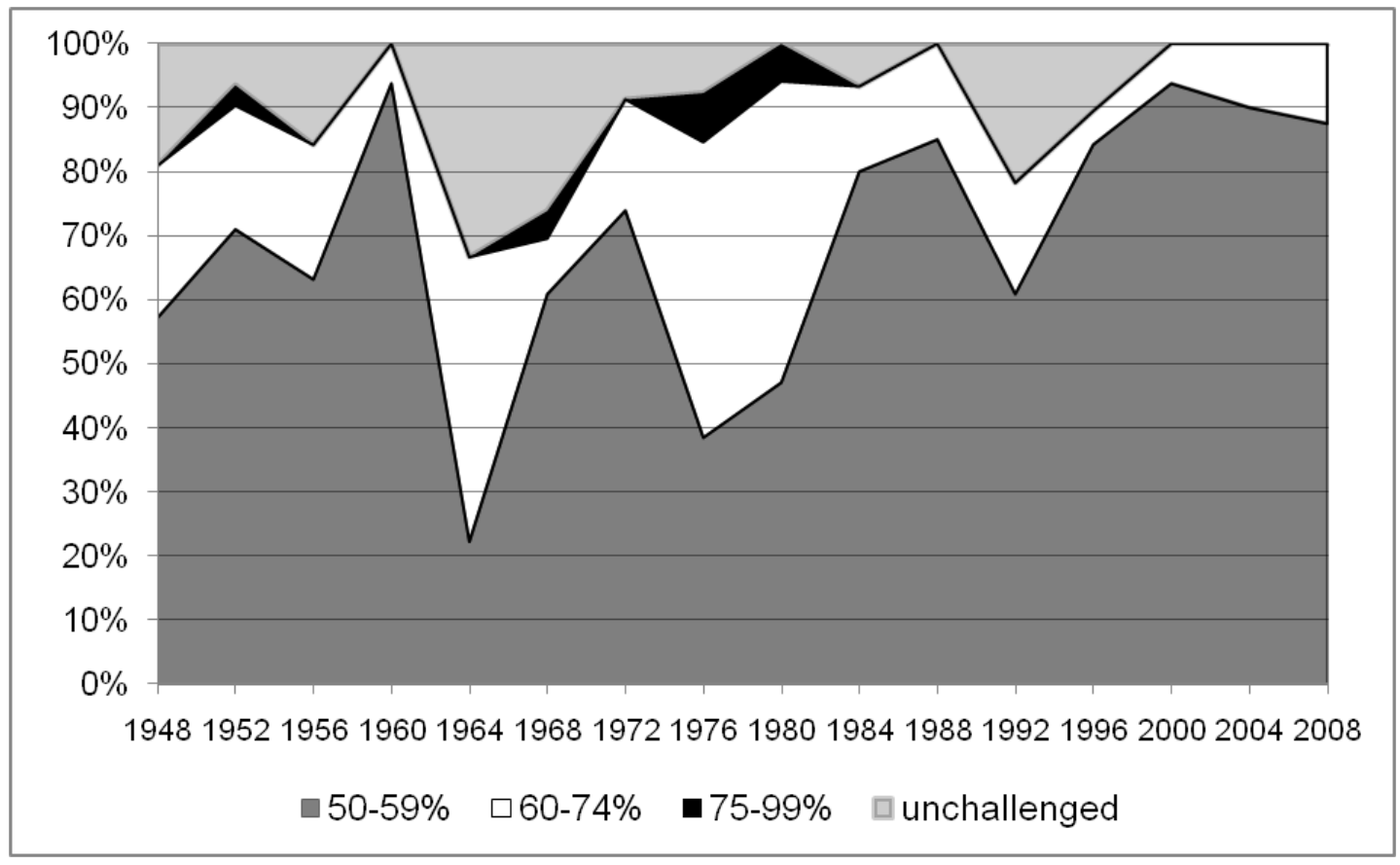


to be in the middle of the period (about 1970 to the mid, or perhaps early, 1980s). In contrast, in partisan and mixed states, the most recent years show the highest levels of competition and there is a period of lesser competition in the middle years (about 1960 to around 1980 ) ${ }^{28}$ Exactly why the patterns for the two broad types of elections may differ is not obvious, although some of what is going on here could again reflect differences due to partisan elections in the South.

Figure 8 shows partisan and mixed elections separately for southern and nonsouthern states. In both regions one sees an increase in competitiveness over time. For the nonsouthern states, this increase occurred in the 1980s. In the South, similar to what occurred in elections with incumbents, there was a decline in competitive elections in the 1960s and 1970s compared to the level in the years examined before 1960 , with an increase starting in the late 70 s or early $80 \mathrm{~s}^{29}$ For the N onsouth, there is no statistically significant pattern of change. Importantly, every one of the 153 open-seat partisan or mixed elections outside the South during the period was contested. In contrast, 19 of the 142 partisan open seat elections in the South went uncontested in both primary and general elections.

A s I noted previously, I believe that the best explanation for what has transpired in the South, and hence the bulk of the change that has occurred in the competitiveness of state supreme court elections, reflects the shift of the southern states from essentially noncompetitive one-party political systems to two-party systems. There is no clear way to "prove" that this is the explanation, but the timing of the shifting patterns in the South seems more consistent with this explanation than the alternatives, and it explains why the bulk of the change has occurred in

\footnotetext{
${ }^{28}$ A GOF chi square test examining the proportion of partisan and mixed elections that are competitive (the winner received less than 60 percent) versus noncompetitive or unopposed does achieve statistical significance $\left(\bullet^{2}=6.98\right.$, $\mathrm{p}=.031$ ). A W ald test based on a dichotomous logistic regression with clustering on state also achieves statistical significance $\left(\bullet^{2}=9.21, p=.010\right)$.

${ }^{29}$ B oth GOF and W ald chi squares (from a dichotomous logistic regression with clustering on state) achieve statistical significance $\left(\mathrm{GOF} \cdot \bullet^{2}=8.33, p=.016 ; \mathrm{W}\right.$ ald $\left.\bullet^{2}=6.87, p=.032\right)$.
} 
FIGURE 8: CONTESTATION AND COM PETITIVENESS, PARTISAN AND MIXED OPEN SEAT ELECTIONS CONTROLLING FOR REGION

\section{(a) SOUTH}

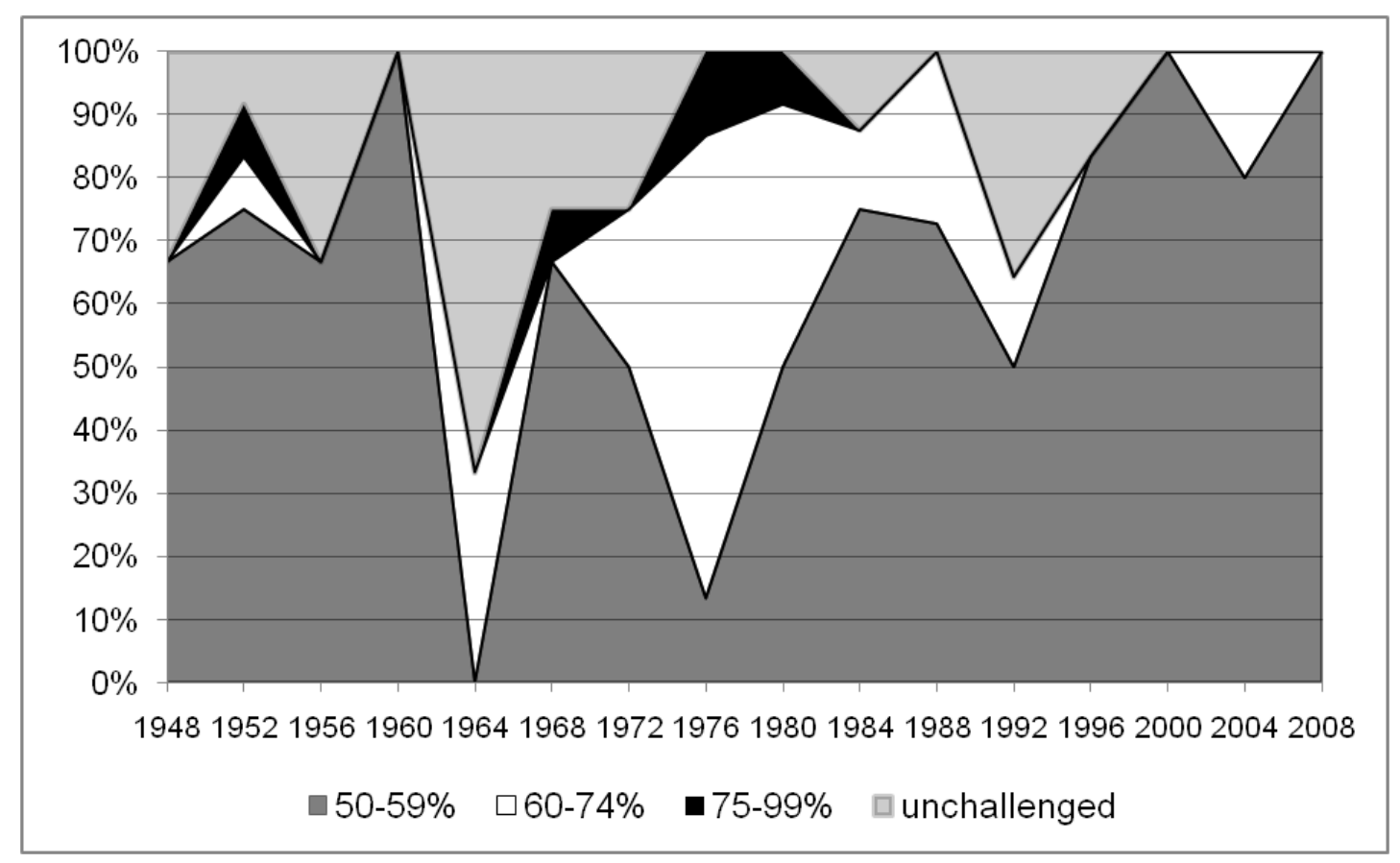

(b) NONSOUTH

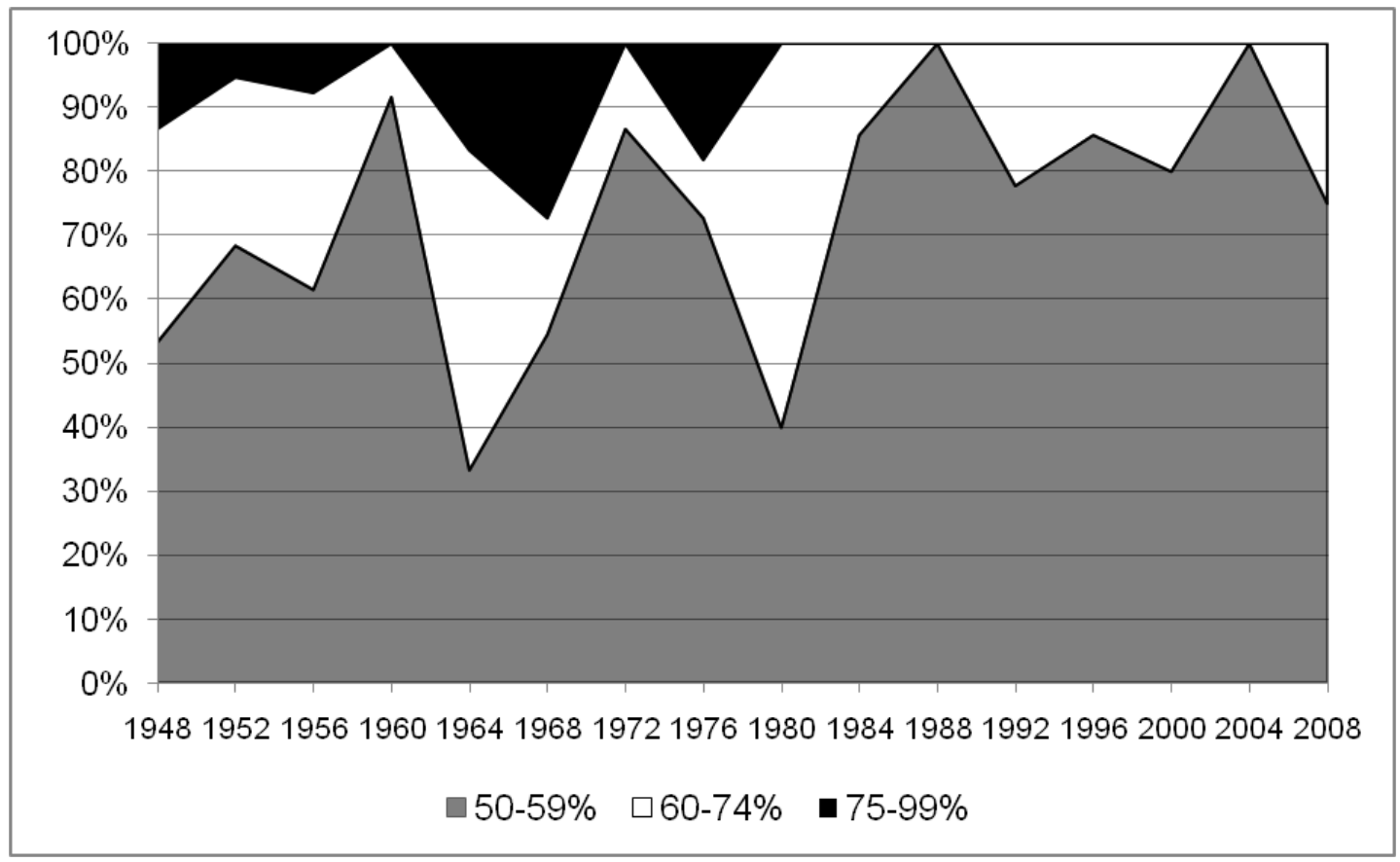


southern states. Figure 9 provides a bit more evidence in support of this explanation. The figure shows two trend lines for partisan elections in the southern states. The gray line (with black markers) shows the percentage of elections that were competitive by my definition (the incumbent lost or the winner obtained less than 60 percent). The black line (with gray markers) shows the percentage of contested elections in which the contest was in the general election (i.e., there was a contested general election and it was closer than the primary election won by the incumbent or eventual winner). The similarity of the two lines is quite strong, and the two series correl ate .75. I interpret this strong relationship as indicative that competitiveness in this set of elections was strongly related to two-party competition.

Undoubtedly there was some increase in expenditures and campaign activity with the emergence of the Republican Party in the South. However, I would argue that those increases were in response to the increased competition rather than being a cause of increased competition. The recent debate has been over whether the sharp increases in expenditures and advertising seen during the last decade has changed the nature of competition in state supreme court el ections. In other words, I am arguing that the changes in the South started around 1980 and were internal to the party system rather than reflecting the role of external players such as interest groups that provide campaign funds and run advertisements. ${ }^{30}$ As the Republican Party became more successful in the South, various external actors increased their activities. Importantly, while such actors also increased their involvement in both partisan and nonpartisan elections outside the

\footnotetext{
${ }^{30}$ According to data assembled by the B rennan Center, state supreme court candidates collected about $\$ 6$ million for the 1989-90 biennium, and about $\$ 9.5$ for the 1991-92 biennium. The next three biennia candidates raised about \$21-27 million. The presidential election biennia of 1999-2000, 2003-04, and 2007-08 saw amounts around \$45 million with the two off-year biennia with amounts on the order of $\$ 30$ million (Sample, Skaggs, Blitzer, and Casey 2010: 5). Thus, the rise in compeitiveness in the South predates the sharp increases in fundraising (and expenditures) that began to take off in the mid-1990s.
} 
FIGURE 9: COMPETITIVENESS AND CONTESTED PARTISAN GENERAL ELECTIONS IN SOUTHERN STATES

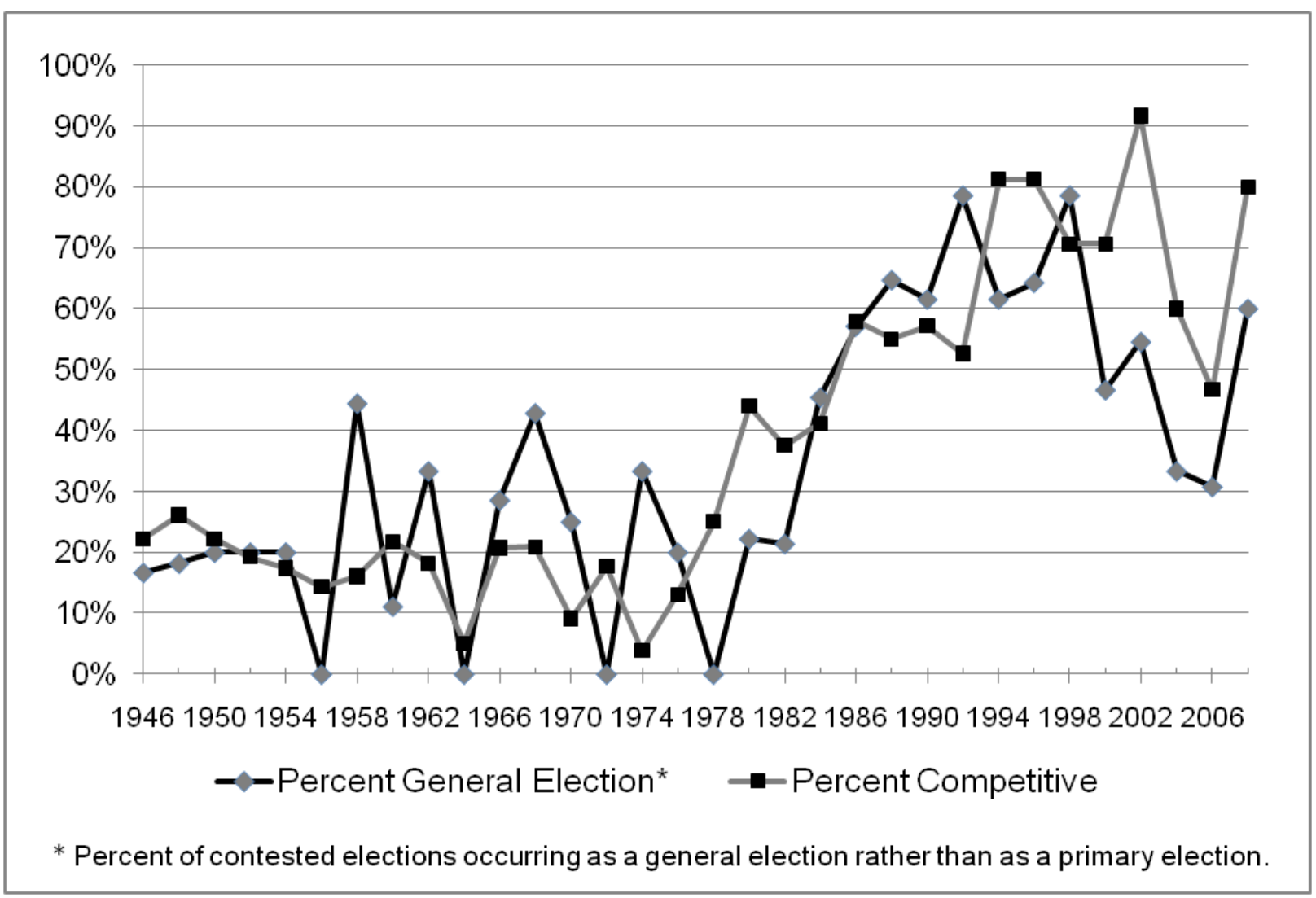

South, one does not see any evidence that their involvement has led to significant increases in the amount of competition.

\section{SUMMARY AND CONCLUSION}

Overall it is accurate to say that state supreme court elections have become more highly competitive, both in terms of more challenges to incumbents and in terms of a higher proportion of elections falling in what I have defined as the competitive range (including incumbents being defeated). However that broad pattern hides important variations, and the analysis shows that 
there are differences if one looks separately at nonpartisan states, partisan and mixed states outside the South, and partisan states in the South.

The strongest pattern revealed by this analysis, other than the marked shift away from using partisan elections, is that much of the change that has occurred has been concentrated in southern states that hold partisan elections for their state supreme courts. In fact, for elections involving incumbents, virtually all the change that has occurred has been in those states; whatever change there has been in contestation and competitiveness in nonpartisan states and in nonsouthern partisan states is minimal at best. For open seat elections there is a pattern of increased competition in partisan and mixed elections in both the South and the Nonsouth, although the specific pattern differs slightly; for nonpartisan states, there has actually been, if anything, a decline in the competitiveness of open seat elections over the last 20 years or so.

Over the last decade, a variety of commentators have argued that judicial elections, particularly those for seats on state supreme courts, have changed as a result of the inflow of substantial sums of money for advertising, either by the candidates' campaigns or as independent expenditures. One can certainly point to specific elections where such advertising appears to have made a difference. A good candidate here is the defeat in A pril 2008 of J ustice L ouis B utler, the first A frican-A merican to serve on the W isconsin Supreme Court (A merican J udicature Society 2010, 224; Sample, Skaggs, Blitzer, and Casey 2010, 32-33). J ustice Butler's opponent, state trial judge M ichael G ableman. Gableman's campaign ran an advertisement described by the President of the State Bar of W isconsin as "disgraceful, deliberately misleading [which was] cast in an offensive, race-baiting style to negatively attack J ustice B utler's role as a former public defender [by] falsely suggest[ing] that a dangerous criminal was released as a 
result of J ustice Butler's work... " (Basting 2008). ${ }^{31}$ This was undoubtedly a nasty el ection; 53 percent of all of the airings of attack advertisements run during 2008 state supreme court elections were aired in Wisconsin, and 59 percent of the airings of ads during that el ection were attack ads. ${ }^{32}$ However, the larger question is how have the changes to campaigning and expenditures that have occurred affected the election process, and particularly to patterns in election outcomes? ${ }^{33}$

Overall, the analysis presented here does not support the proposition that patterns in aggregate election results have changed markedly due to any changes over the last 15-20 years in how state supreme court campaigns are conducted. The major change that one sees in looking over the last 64 years reflects the shift of the South from one-party Democratic, to competitive, and in some states to what in the most recent years has been clear Republican dominance. The remaining changes regarding aggregate election results are relatively small. Thus, leaving aside the broad changes that have occurred in the southern states, the picture that emerges from this analysis is, perhaps surprisingly, one of relatively stability.

\footnotetext{
${ }^{31}$ The state J udicial Commission brought charges against J ustice Gableman for actions during his campaign, but ultimately dropped those charges (in J uly 2010) after the six other members of the W isconsin Supreme Court split 33 on whether his behavior was a violation and how to proceed further with the case. Previously a three-judge panel had found that Gableman had recommended dismissing the case on the grounds that the advertisement had not contained false information (see Patrick M arley, "W ith Supreme Court Deadlocked, Commission D rops Gableman E thics Case," M ilwaukee J ournal Sentinel, http://www.jsonline.com/news/statepolitics/98037184.html, posted J uly 8, 2010 [lasted visited J uly 30, 2010]).

32 These figures were compiled from information in the 2010 B rennan Center report (Sample, Skaggs, B litzer, and Casey 2010,86-97).

${ }^{33}$ This is by no means the only question one can ask about increasing prevalence of high volume television advertising in judicial election campaigns. A nother issue, which I do not address, is on the public's view of the courts (see Gibson 2009).
} 


\section{Appendix A: Number of Each Type Of Election by Year}

TABLE A1: NUMBERS OF ELECTIONS REPRESENTED IN FIGURES

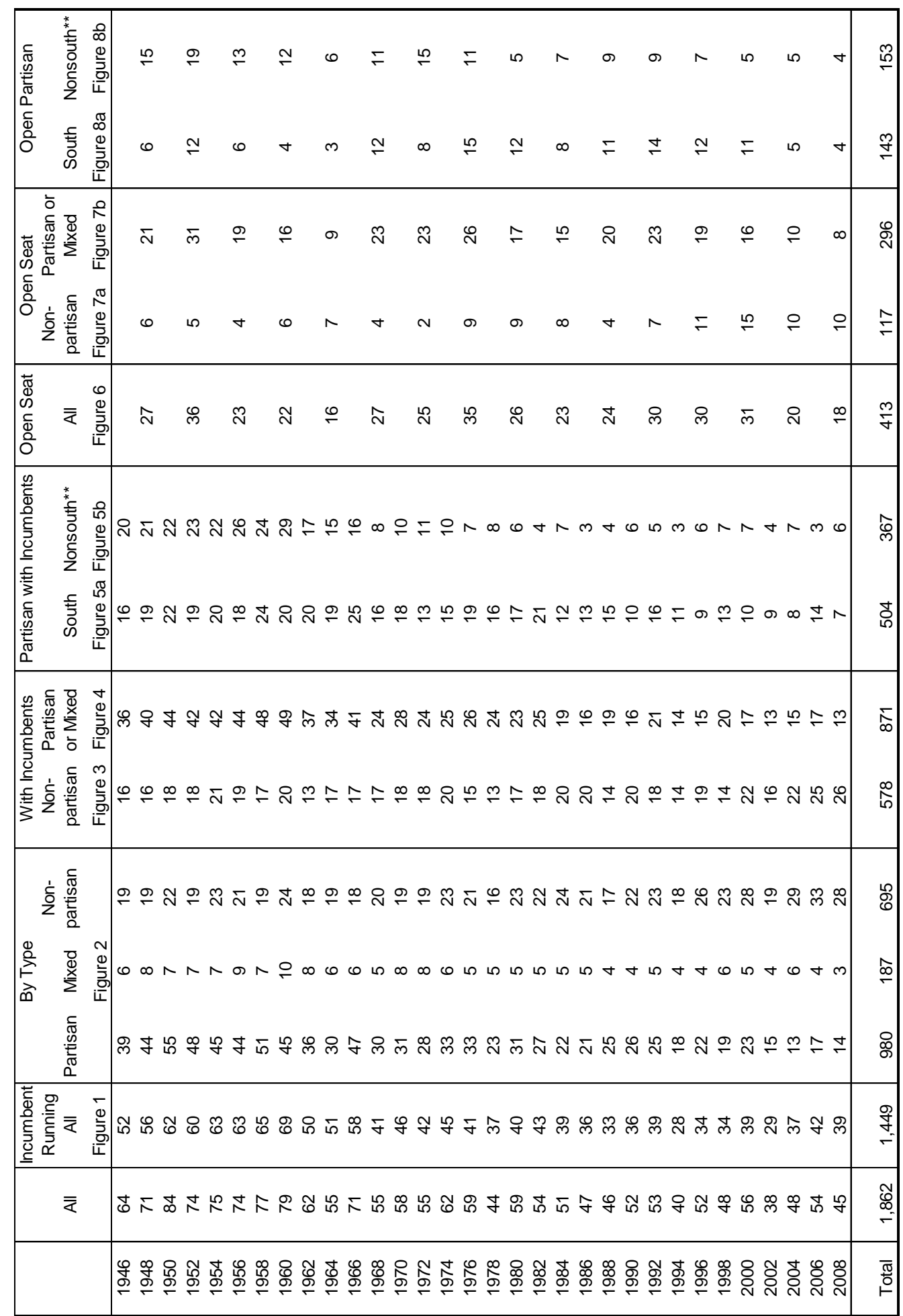




\section{FIGURE B1: CHANGES IN TYPE OF ELECTIONS FOR STATE SUPREME COURT}

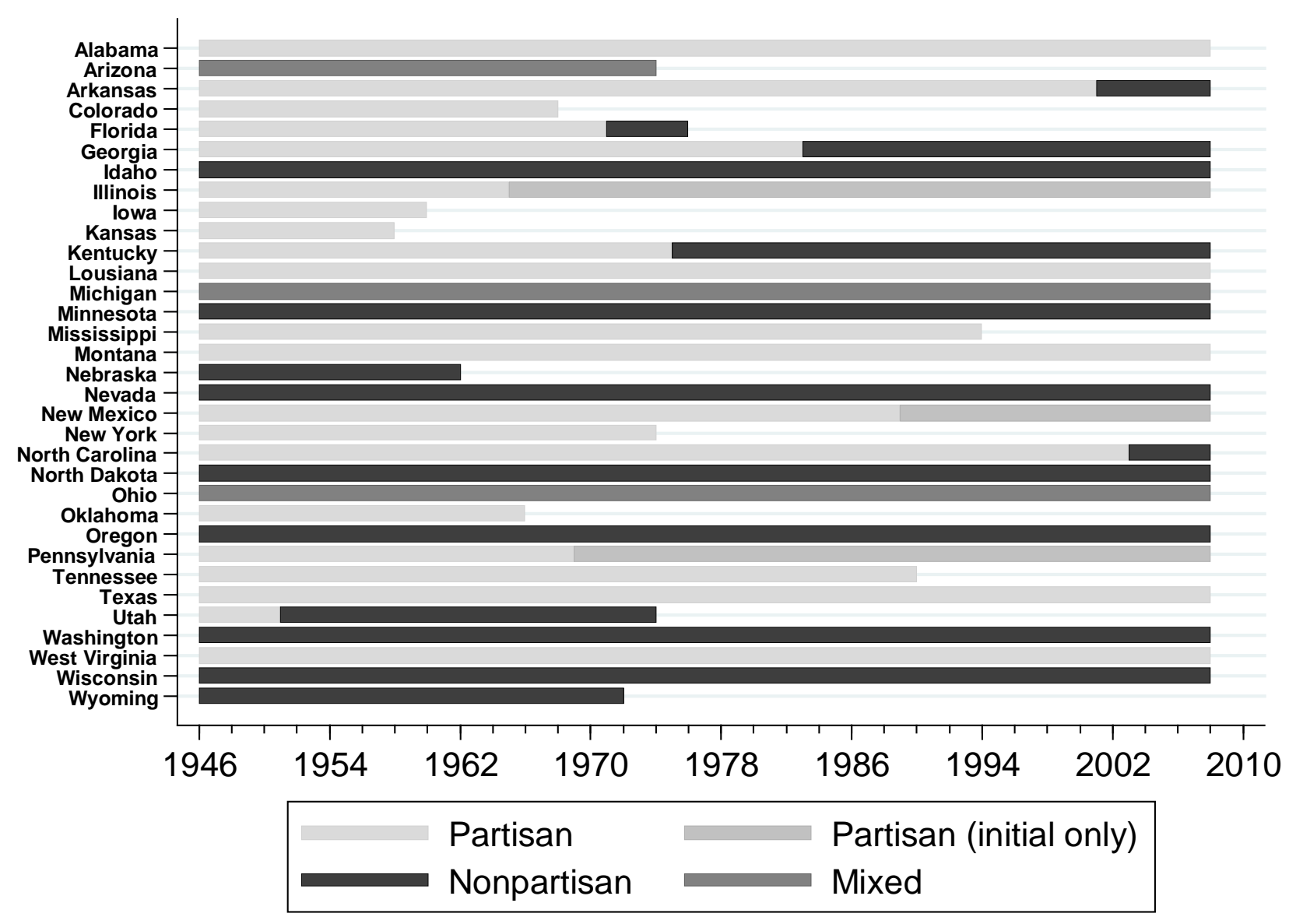




\section{REFERENCES}

A merican Judicature Society (2010) "Editorial: What Should J udicial Candidates Talk to V oters A bout?" 93 J udicature 224.

A rbour, Brian K. and M ark J. M cK enzie (2010) "Has the 'N ew Style' of J udicial Campaigning Reached Lower Court Elections?" 93 J udicature 150.

A spin, Larry (2007) "J udicial Retention Election Trends, 1964-2006." 90 J udicature 208.

Basting, Thomas J ., Sr. (2008) "Gutter Politics and the W isconsin Supreme Court." Wisconsin Lawyer, May, pp. 5.

Black, M erle (2004) "The Transformation of the Southern Democratic Party." $66 \mathrm{~J}$ ournal of Politics 1001.

B onneau, Chris W. and M elinda Gann Hall (2009) In D efense of J udicial Elections. N ew Y ork: Routledge.

Dubois, Philip L. (1980) From Bench to Ballot: J udicial Elections and the Quest for Accountability. A ustin: University of Texas Press.

Gibson, James L. (2009) "'N ew-Style' J udicial Campaigns and the Legitimacy of State High Courts." 71 J ournal of Politics 1285.

Goldberg, Deborah, Craig Holman, and Samantha Sanchez (2000) "The N ew Politics of J udicial Elections: How 2000 W as a W atershed $Y$ ear for Big M onay, Special Interest Pressure, and TV A dvertising in State Supreme Court Campaigns." N ew Y ork: B rennan Center for J ustice, N ew Y ork University School of Law [http://www.justiceatstake.org/media/cms//A A SM oneyReport_E 7C 1343619C 9F.pdf].

Goldberg, Deborah, Sarah Samis, Edwin Bender, and Rachel Weiss (2004) "The N ew Politics of J udicial Elections 2004: How Special Interest Pressure on Our Courts Has R eached a "Tipping Point"--and How to K eep Our Courts Fair and Impartial." N ew Y ork: Brennan Center for J ustice, N ew Y ork U niversity School of Law [http://brennan.3cdn.net/dd00e9b682e3ca2f17_xdm6i068k.pdf].

Goldberg, Deborah and Samantha Sanchez (2004) "The N ew Politics of J udicial Elections 2002: How the Threat to Fair and Impartial Courts Spread to M ore States in 2002." N ew Y ork: B rennan Center for J ustice, N ew Y ork University School of Law [http://brennan.3cdn.net/3e06222f06bc229762_yom6bgubs.pdf].

Hall, M elinda Gann (2001) "State Supreme Courts in A merican Democracy: Probing the M yths of J udicial Reform." 95 American Political Science Review 315.

-.--- (2007) "Competition as A ccountability in State Supreme Court Elections," in M. J. Streb, ed., Running for J udge: The Rising Political Financial, and Legal Stakes of J udicial Elections. N ew Y ork: N ew Y ork University Press. 
----- (2011) "On the Cataclysm of J udicial Elections and Other Popular A nti-Democratic M yths," in C. Geyh, ed., What's Law Got to Do With it: What J udges Do and Why it $M$ atters. Stanford, CA: Stanford University Press.

Huber, Gregory A . and Sanford C. Gordon (2004) "A ccountability and Coercion: Is J ustice Blind when It Runs for Office?" 48 American J ournal of Political Science 247.

K ritzer, Herbert M . (2007) "'Law Is the M ere Continuation of Politics by Different M eans': A merican Judicial Selection in the 21st Century." 56 D eP aul Law Review 423.

Sample, J ames, L auren Jones, and Rachel W eiss (2007) "The N ew Politics of J udicial Elections 2006: How 2006 W as the M ost Threatening Y ear $Y$ et to the Fairness and Impartiality of Our Courts--and How A mericans A re Fighting B ack." N ew Y ork: B rennan Center for J ustice, New Y ork University School of Law [http://brennan.3cdn.net/49c18b6cb18960b2f9_z6m62gwji.pdf].

Sample, J ames, A dam Skaggs, J onathan Blitzer, and Linda Casey (2010) "The N ew Politics of Judicial Elections 2000-2009: Decade of Change." N ew Y ork: Brennan Center for Justice, N ew Y ork University School of Law.

Schwartz, J ohn (2009) "Effort B egun to End V oting for J udges." N ew York Times, December 24, 2009. 